\title{
Coping up with Risks to Increase Sustainability: Strategies for Small-scale Shrimp Farming in Indonesia
}

\author{
Riski A. Lestariadi ${ }^{1}$ and Masahiro Yamao ${ }^{2}$ \\ ${ }^{1}$ Faculty of Fisheries and Marine Science, Brawijaya University, Indonesia \\ ${ }^{2}$ Food Production Management Laboratory, Department of Bio Resource Science, \\ Graduate School of Biosphere Science, Hiroshima University, \\ 1-4-4 Kagamiyama, Higashi-Hiroshima, Japan
}

\begin{abstract}
Small-scale shrimp farmers have contributed significantly in increasing shrimp production in Indonesia. However, they face various risks that resulted to high fluctuation in their income. Risk management strategies in shrimp farming are needed to cope with inherent risks in order to enhance sustainability of shrimp farming. This study analyzed the sources of risks, ex-ante risk management and ex-post risk coping strategies in small-scale shrimp farms in Indonesia. A field survey of 166 shrimp farmers was conducted in the North and South coastal zones of East Java. Results revealed that the top three sources of risks that influenced in shrimp farming were shrimp price volatility, high mortality due to diseases, and increasing formulated feed price. Requesting for government technical assistance was the common formal onfarm risk management strategy used by the shrimp farmers. Sharecropping was the main ex-ante strategy to mitigate risk. Small-scale shrimp farmers tended to avail of informal loans that resulted to loss of savings. They also used family labor as informal ex-post strategy to reduce expenses. They used social assistance from the government as formal ex-post risk coping strategies.
\end{abstract}

Keywords: Aquaculture risk, shrimp farming, sustainability of shrimp farming, risk management strategies, Indonesia

\section{INTRODUCTION}

Indonesian aquaculture has grown significantly in the last decade. Aquaculture production continues in a positive trend that resulted in a $36.6 \%$ growth during the past 15 years. According to FAO (2016) Indonesia has become the second biggest aquaculture producers in the world. The total Indonesian aquaculture production reportedly reached 4.253 thousand metric tons, which contributed $5.77 \%$ of world's total

Correspondence: Riski A. Lestariadi Address: Graduate School of Biosphere Science, Hiroshima University, 1-4-4 Kagamiyama, Higashi-Hiroshima, Japan E-mail:d150559@hiroshima-u.ac.jp DOI: $10.32945 /$ atr3911.2017 
production. Seaweed, milkfish and shrimp were the major commodities in Indonesia during the 2000-2015 period (FAO 2016). Shrimp was the leading Indonesian fisheries export in terms of value for a couple of years (Ministry of Marine \& Fisheries 2015).

The fast growth of shrimp production brought many opportunities, including increasing foreign exchange, creating job opportunities and improving shrimp farmers' income. The business environment of shrimp

farms has changed due to the aforementioned conditions. The spread of shrimp diseases, environmental degradation, shrimp price fluctuation and product rejection by importing countries were some of the few issues that affected Indonesian shrimp production in the last several years (Sustainable Fisheries Partnership 2013, Undercurrent News 2014, Kilawati et al 2015).

Increasing shrimp price and high demand in both international and domestic markets resulted to some economic advantages to Indonesian shrimp farmers. The shrimp farmers responded to those conditions by applying a new technology in shrimp cultivation, particularly the intensive system. This system allows them to cultivate shrimp with higher stocking density thus increasing productivity. However, it also brought more risks to shrimp farms: production, marketing, personal and institutional risks. Thus a risk management system became increasingly needed to enhance the ability of shrimp farmers to deal with risks as well as maintain the sustainability of their livelihood.

The primary objective of this paper was to explore risk management strategies of small-scale shrimp farmers in East Java, Indonesia. Specifically, it examined the sources of risk and determined the ex-ante and ex-post risk management strategies shrimp farmers employed.

\section{Risk Management Strategies}

A critical issue in developing countries like Indonesia, where the economic environment is riskier, is to understand the way in which risk affects household choices to deal with risks (Murdoch 1994, Dercon 2005). There are two components of risks related to different aspects of shrimp farmers' decisions. The first is the possibility of unforeseeable future events. This component leads the shrimp farmers to try to reduce future risks and their consequences. This is referred to as ex-ante risk management strategy. The second is the actual occurrence of shocks. This component pushes shrimp farmers to cope with the effects of shock when it occurs. This referred to as ex-post risk management strategy.

Ex-ante risk management and ex-post risk coping strategies could be defined as measures taken before and after experiencing shock, respectively (Lekprichakul 2009). A shock is an unpredicted or unfavorable event that effects fluctuation in shrimp farmers' income. 
Ex-ante risk management strategies that are undertaken before a shock occurs include risk avoidance, risk reduction and risk transfer (Chuku 2009). These strategies are taken to minimize the impact of a shock when it occurs. Makoka (2008) said that the purpose of ex-ante risk management strategies is to reduce fluctuation in farmers' income. Furthermore, if shrimp farmers fail to manage the shock ex-ante, they develop strategies to cope with the shock. This is called ex-post coping strategy which is aimed at reducing fluctuation in consumption and assets protection.

\section{Risk Management Mechanisms}

In exploring how to manage the risk in small-scale shrimp farms, it is useful to distinguish between strategies and mechanisms used by farmers in dealing with risk. The World Bank (2005) highlighted two mechanisms regarding risk management mechanisms in agriculture: informal and formal.

Informal mechanisms involve individuals, household or communities. Informal ex-ante strategies with informal mechanism are characterized by diversification of income sources and choice of production strategy. Informal ex-ante strategies are classified into two: onfarm and risksharing. Table 1 shows that onfarm ex-ante strategies include risk avoidance, crop diversification, diversification of income sources, buffer stock accumulation of crop or liquid assets and adoption of advanced technology (World Bank 2005). Ex-ante strategies are classified as risksharing include sharecropping, sharing equipment, and informal risk pooling (Gunning 2012). Informal ex-post mechanisms consist of sale of assets or reallocation of labor resources, reduced consumption pattern, and migration (Perdana 2005).

Table 1. Mechanisms in Risk management Strategies

\begin{tabular}{|c|c|c|c|c|}
\hline & & \multirow[t]{2}{*}{ Informal Mechanism } & \multicolumn{2}{|c|}{ Formal Mechanism } \\
\hline & & & Market Based & Government Support \\
\hline \multirow[t]{2}{*}{$\begin{array}{c}\text { Ex-Ante } \\
\text { Strategies }\end{array}$} & On Farm & $\begin{array}{ll}\text { - } & \text { Risk avoidance } \\
\text { - } & \text { Risk Reduction } \\
\text { - } & \text { Diversification of } \\
\text { income sources } \\
\text { - } & \text { Buffer stock } \\
\text { - } & \text { accumulation } \\
\text { Adoption advanced } \\
\text { technique }\end{array}$ & - & $\begin{array}{l}\text { - Aquaculture extension } \\
\text { - Subsidy or supply of } \\
\text { quality seeds, inputs, } \\
\text { etc. }\end{array}$ \\
\hline & $\begin{array}{l}\text { Sharing } \\
\text { the Risk }\end{array}$ & $\begin{array}{ll}\text { - } & \text { Sharecropping } \\
\text { - } & \text { Sharing equipment } \\
\text { - } & \text { Informal risk pooling }\end{array}$ & $\begin{array}{l}\text { - } \quad \text { Contract marketing } \\
\text { - Insurance }\end{array}$ & - \\
\hline $\begin{array}{l}\text { Ex-Post } \\
\text { Strategies }\end{array}$ & $\begin{array}{l}\text { Coping } \\
\text { the Risk }\end{array}$ & $\begin{array}{ll}\text { - } & \text { Reduce consumption } \\
\text { - } & \text { Sattern } \\
\text { - } & \text { Reallo of assets } \\
\text { - } & \text { Mutual aid }\end{array}$ & - $\quad$ Credit & $\begin{array}{l}\text { - } \quad \text { Social assistance } \\
\text { - } \quad \text { Cash transfer }\end{array}$ \\
\hline
\end{tabular}

World Bank (2005) 
Formal mechanisms are arrangements that include market-based activities and government support or publicly-provided strategies. Extension support from government, subsidy for onfarm inputs and infrastructure are publicly provided strategies that could be classified as formal onfarm ex-ante mechanism. Ex-ante risk sharing strategies include marketing contract, production contract and insurance. According to Gunning (2012) formal ex-post strategies consists market-based strategies in the form financial institutions and publicly-provided strategies in the form of social assistance and cash transfer from the government.

\section{MATERIALS AND METHODS}

This study used data from small-scale shrimp farms in East Java, Indonesia. Surveys were conducted in both the south and north coastal areas of East Java. Two regencies were selected: Banyuwangi Regency in the south coastal area and Lamongan Regency in the north. These regencies were purposely selected because they are the main shrimp producing areas in East Java. The sample included 79 and 87 shrimp farms in south and north coastal areas, respectively.

Before designing the survey, indepth interviews with experts in shrimp farming were conducted to collect opinion and suggestions related to sources of risk and risk management strategies. Based on indepth interview with the experts, the researchers developed the questionnaire that included 32 sources of risk and 34 risk-management strategies were presented to the respondents. A 5-point Likert scale was employed to measure impact of sources of risk and likelihood of their occurrence. A rating of 1 represented minor impact of the risk on shrimp farm, while 5 represented severe impact. Similarly, the likelihood of risk occurrence was measured on 1-5 scale, with 1 representing rare incidence and 5 representing almost certain occurrence. The level of risk was defined as the likelihood of the risk occurring and its consequences. Next, risks and risk management strategies were ranked by their means in descending order to evaluate the level of risk and the effectiveness of risk management strategies. Descriptive statistical analysis was used to interpret the results.

\section{RESULTS AND DISCUSSION}

\section{Sources of Risk in Small-scale Shrimp Farming}

Table 2 presents the 32 sources of risk. The level of risk is presented in the fourth column of Table 2; consequences and likelihood are in the second and third columns, respectively. 
Table 2. Consequences, likelihoods, and levels of risk

\begin{tabular}{|c|c|c|c|c|}
\hline Sources of Risk & Consequence $^{\mathrm{a}}$ & Likelihood $^{\mathrm{b}}$ & Risk Level $^{\mathbf{c}}$ & Rank \\
\hline Shrimp price volatility & 4.921 & 4.450 & 21.897 & 1 \\
\hline High mortality due to diseases & 4.926 & 4.434 & 21.841 & 2 \\
\hline Increasing formulated feed price & 4.643 & 4.035 & 18.734 & 3 \\
\hline $\begin{array}{l}\text { Water pollution due to excessive } \\
\text { formulated feed }\end{array}$ & 4.561 & 3.492 & 15.924 & 4 \\
\hline Low quality of shrimp fries & 4.921 & 3.040 & 14.957 & 5 \\
\hline Not enough formulated feed supply & 3.899 & 3.527 & 13.752 & 6 \\
\hline $\begin{array}{l}\text { Shrimp farmers do not have brackish } \\
\text { water treatment facility }\end{array}$ & 4.843 & 2.839 & 13.750 & 7 \\
\hline $\begin{array}{l}\text { Not enough capital for operating shrimp } \\
\text { farms }\end{array}$ & 4.091 & 3.306 & 13.528 & 8 \\
\hline Low quality of formulated shrimp feed & 4.899 & 2.712 & 13.286 & 9 \\
\hline Feeding management failure & 4.503 & 2.929 & 13.186 & 10 \\
\hline $\begin{array}{l}\text { Lack of knowledge to prevent shrimp } \\
\text { diseases }\end{array}$ & 3.889 & 3.257 & 12.665 & 11 \\
\hline Polluted brackish water sources & 4.651 & 2.709 & 12.597 & 12 \\
\hline Excessive stocking density & 3.593 & 3.399 & 12.213 & 13 \\
\hline $\begin{array}{l}\text { Changed government policy and } \\
\text { regulation }\end{array}$ & 4.254 & 2.861 & 12.170 & 14 \\
\hline $\begin{array}{l}\text { Lack of information about the origin of } \\
\text { shrimp fries }\end{array}$ & 3.958 & 2.902 & 11.486 & 15 \\
\hline Lack of knowledge of pond preparation & 4.216 & 2.682 & 11.307 & 16 \\
\hline Inappropriate pond location & 4.249 & 2.648 & 11.251 & 17 \\
\hline $\begin{array}{l}\text { Do not conduct treatment before stocking } \\
\text { shrimp fries }\end{array}$ & 3.714 & 2.971 & 11.035 & 18 \\
\hline Lack collateral for loan & 3.762 & 2.890 & 10.874 & 19 \\
\hline Lack of labor knowledge & 3.978 & 2.698 & 10.733 & 20 \\
\hline Shrimp size variability & 3.376 & 3.130 & 10.565 & 21 \\
\hline Inappropriate pond design & 3.423 & 3.077 & 10.532 & 22 \\
\hline Brackish water quality & 3.016 & 3.393 & 10.234 & 23 \\
\hline Inappropriate harvesting method & 3.524 & 2.749 & 9.686 & 24 \\
\hline Harvesting without grading & 3.545 & 2.696 & 9.556 & 25 \\
\hline $\begin{array}{l}\text { Asymmetric information between buyer } \\
\text { and farmers }\end{array}$ & 3.478 & 2.690 & 9.359 & 26 \\
\hline Inappropriate shrimp fries size & 3.143 & 2.902 & 9.121 & 27 \\
\hline High interest rate for loan & 3.392 & 2.638 & 8.948 & 28 \\
\hline Not enough labor supply & 3.184 & 2.628 & 8.368 & 29 \\
\hline Flood & 3.026 & 2.575 & 7.793 & 30 \\
\hline High wages of hired labor & 3.039 & 2.553 & 7.760 & 31 \\
\hline $\begin{array}{l}\text { Low level of awareness among shrimp } \\
\text { farmers }\end{array}$ & 2.724 & 2.693 & 7.335 & 32 \\
\hline
\end{tabular}

Note: a) Consequence was measured using 5 -point Likert scale ( 1 minor impact; 5 catastrophic).

b) Likelihood was measure d using 5 -point Likert scale (1 rare; 5 almost certain).

c)1.000-5.000, very low risk; 5.001-10.000, low risk; 10.001-15.000, moderate risk; 15.001-20.000, high risk; 20.001-25.000, very high risk level.

The result revealed that two sources of risk, shrimp price vitality and high mortality due to diseases, were classified as very high risk with the potential of having the most severe impact on shrimp farmers' income. The second level consists of two sources of risk, increasing formulated feed price and water pollution due to excessive formulated feed, were classified as a high. The remaining 28 sources were classified as moderate with ratings between 10.0 and 14.9. These indicators need serious attention for risk management for small-scale shrimp farming in Indonesia. 
Shrimp price vitality as the top source of risk shows that the majority of farmers have been cultivating shrimp without any marketing contract or insurance. Shrimp price fluctuation has been triggered by the spread of shrimp diseases, such as Infectious Mionecrosis Virus (IMNV), White Spot Syndrome Virus (WSSV) and White Feces Disease (WFD). It is not surprising then that high mortality due to diseases was the second-ranked source of risk.

Increasing formulated feed price ranked third and classified as high of risk. Formulated feed price has a major impact on shrimp farms' income. Hung and Quy (2013) found that formulated feed cost comprises 66 to $68 \%$ of the total production cost in intensive shrimp farming system.

Water pollution due to excessive formulated feed ranked fourth and classified as moderate. This is the usual shrimp farming technique that has been practiced by shrimp farmers. Shrimp farmers used feeding trays to monitor consumption level and to adjust the next feeding ration. This method is highly dependent on shrimp farmers' experience to estimate the amount of formulated feed for the next feeding ration. If the shrimp farmers failed to determine the appropriate amount of feed, the shrimp pond is saturated with uneaten feed that can reduce the quality of the brackish water and produce toxic substances.

It is noteworthy to mention that small-scale shrimp farmers in East Java ranked the risks rather differently compared to farmers in other countries. For example, marketing risk was perceived as the biggest source of risk by a group of Dutch farmers (Meuwissen 2001) and New Zealand farmers (Martin 1996), while production risk was the top-source of risk in America (Knutson et al 1998, Harwood et al 1999, Hall et al 2003). This might be explained by the fact that socio-economic characteristics of smallscale shrimp farmers in East Java impacts their perceptions of the sources of risk.

\section{Risk Management Strategies in Small-scale Shrimp Farming}

In this study, risk management strategies were measured by shrimp farmers based on the strategy's efficacy to mitigate each source of risk. A 5point Likert scale was employed to measure risk management strategies, with 1 representing negligible effect while 5 for most significant effect. The average score of the efficacy of the formal and informal risk management strategies are presented in Table 3 and 4, respectively. The top ten risk management strategies used by small-scale shrimp farmers in the research areas were: strict management of water quality, strict feeding management, following better management practices, buying fries only from reliable source, using shrimp fries that have SPF certificate, production contract, contract for shrimp farms input, partial harvesting, attending workshop on shrimp farming, and sharecropping. 
Ex-ante RiskManagement Strategies

\section{a. Informal Mechanism}

Table 3 shows respondents' onfarm ex-ante strategies. Most farmers used the informal mechanisms to manage risks, which are characterized by diversification of their income sources and choice of production strategy.

\begin{tabular}{|c|c|}
\hline $\begin{array}{c}\text { Ex-Ante } \\
\text { Strategies }\end{array}$ & Informal Mechanism \\
\hline \multirow[t]{4}{*}{ On Farm } & $\begin{array}{l}\text { 1) Risk Reduction } \\
\text { - Strictly manage water quality (5.000) } \\
\text { - Strictly feeding management (4.989) } \\
\text { - Applying better management practices (4.910) } \\
\text { - Partial harvested (4.672) } \\
\text { - Attending workshop in shrimp farming (4.545) } \\
\text { - Prevent shrimp diseases by regular checking (4. } \\
\text { - Develop brackish water treatment (3.543) } \\
\text { - Hire technical assistant (3.439) }\end{array}$ \\
\hline & $\begin{array}{l}\text { 2) Risk avoidance } \\
\text { - Only buy shrimp fries from reliable place }(4.78 \\
\text { - Only buy shrimp fries that have SPF certificate } \\
\text { - Reduce brackish water pond size }(4.405) \\
\text { - Reduce stocking density }(4.222) \\
\text { - Reallocated shrimp pond to designed area }(4.11 \\
\text { - Buying formulated feed from reliable brands }(3 \\
\text { - Make credit arrangement before production cyc } \\
\text { - Enforcing the shrimp pond dike }(3.429) \\
\text { - Use large size shrimp fries }(2.757) \\
\text { - Follow the government policy and regulation (1 }\end{array}$ \\
\hline & $\begin{array}{l}\text { 3) Adoption advanced technique } \\
\text { - Apply new technology in shrimp production ( } 2 \text {. }\end{array}$ \\
\hline & $\begin{array}{l}\text { 4) Diversification of income sources } \\
\text { - Farm diversification }(3.291) \\
\text { - Off-farm work }(1.196)\end{array}$ \\
\hline \multirow[t]{3}{*}{ Sharing the Risk } & $\begin{array}{l}\text { 1) Sharecropping } \\
\text { - Sharecropping (4.517) }\end{array}$ \\
\hline & $\begin{array}{l}\text { 2) Informal risk pooling } \\
\text { - Informal marketing contract with wholesaler ( } 2\end{array}$ \\
\hline & $\begin{array}{l}\text { 3) Sharing equipment } \\
\text { - Sharing machinery and paddle wheels (1.958) }\end{array}$ \\
\hline
\end{tabular}

Among strategies in onfarm informal mechanisms, strict management water quality was regarded as the most effective, followed by strict feeding management and applying better management practices for the second and third ranks, respectively. The average score of these strategies was 
classified according to their effectiveness in mitigating shrimp farming risks, such as high mortality due to diseases and water pollution due to excessive formulated feed.

It was a surprise that reducing stocking density ranked ninth among informal mechanisms of ex-ante risk management. Instead of avoiding profit loss by reducing stocking density, the farmers had been maintaining their shrimp farms at a higher stocking density level to get more profit. This implied that respondents were risk-takers. The reason came from the increasing shrimp price in the last several years due to excessive demand in the international market. The demand was inadequately met because of lowered shrimp production in several shrimp exporting countries due to the Early Mortality Syndrome (EMS). With regards to risk sharing ex-ante strategies, the results showed that sharecropping was the main informal strategy, followed by informal marketing contract with wholesaler and sharing machinery and paddle wheels among shrimp farms in the second and third ranks, respectively.

\section{b. Formal Mechanism}

Table 4 presents the formal ex-ante risk management strategies. Three strategies were classified as the most effective with average scores of between 4.00 and 5.00. These strategies are production contract (4.767), contract for farms inputs (4.691) and vertical integration (4.212). Results implied that the shrimp farmers tried to reduce their risks by sharing them with third parties. Production contract strategy was the most effective mechanism to mitigate risk related to output, while the contract for shrimp farm inputs was effective to alleviate risk associated with input, such as formulated feed, machinery and paddle wheel.

For onfarm formal mechanism, request government support for technical assistance registered an efficacy rating of 4.135. It is followed by buying shrimp fries from the public hatchery with a score of 3.016. This strategy has a strong correlation with the eighth-ranked source of risk in Table 2, which is not enough capital to operate shrimp farms. Shrimp fries from public hatchery are cheaper than those from the private hatchery. Shrimp farmers used this strategy to reduce production cost. Small-scale shrimp farmers in the research areas did not use the formal ex-ante strategies with market-based mechanisms. 
Table 4. Ex-ante risk management strategies with formal mechanisms

\begin{tabular}{|c|c|c|}
\hline \multirow{2}{*}{ EX-Ante Strategies } & \multicolumn{2}{|c|}{ Formal Mechanism } \\
\hline & Market Based & Government Support \\
\hline \multirow[t]{2}{*}{ On Farm } & & $\begin{array}{l}\text { 1) Aquaculture extension } \\
\text { - Request government support for technical } \\
\text { assistant (4.135) }\end{array}$ \\
\hline & None & $\begin{array}{l}\text { 2) Subsidy or supply of fries, inputs, etc. } \\
\text { - Buying shrimp fries from public hatchery } \\
\text { (3.016) }\end{array}$ \\
\hline Sharing the Risk & $\begin{array}{l}\text { 1) Insurance } \\
\text { - Production contract (4.767) } \\
\text { - Contract for shrimp farms inputs (4.691) } \\
\text { - Vertical integration (4.212) }\end{array}$ & None \\
\hline & $\begin{array}{l}\text { 2) Contract marketing } \\
\text { - Marketing contract with processor } \\
(3.799)\end{array}$ & \\
\hline
\end{tabular}

\section{Ex-post Risk Coping Strategies}

Table 5 and 6 present the average efficacy score of each ex-post risk coping strategies. The purpose of ex-post strategies was to reduce fluctuations in consumption and assets of shrimp farmers' household.

\section{a. Informal Mechanism}

The result revealed that five ex-post strategies had been used by the shrimp farmers to cope with risks. Due to lack of collateral and high interest rate for loan, small-scale shrimp farmers tend to used informal loan and dissaving as ex-post risk coping strategies. However, only use informal loan strategies (3.716) had average effective, while the three remaining strategies had little efficacy in mitigating impact of risk. Furthermore, to reduce expenditure in shrimp production, the small-scale shrimp farmers used family labor (2.106). This strategy was effective in coping with the external risk, such as increasing wages of hired labor and inadequate of labor supply.

Table 5. Ex-post risk coping strategies with informal mechanism

\begin{tabular}{ll}
\hline $\begin{array}{c}\text { Ex-Post } \\
\text { Strategies }\end{array}$ & Informal Mechanism \\
\hline Coping the Risk & 1) Mutual aid \\
$\bullet$ & Use informal loan (3.716) \\
2) Reduce consumption pattern & Change consumption pattern (2.762) \\
3) Reallocation of labor \\
Use family labor (2.1 06) \\
4) Sale of assets \\
$\bullet$ Dissaving (2.093) \\
\hline Note: Number in parenthesis represent the level of risk: 1.000-5.000, very low risk; \\
5.001-10.000, low risk; 10.001-15.000, moderate risk; 15.001-20.000, high \\
risk; $20.001-25.000$, very high risk level.
\end{tabular}




\section{b. Formal Mechanism}

Table 6 shows that requesting for social assistance from the government was the only ex-post risk coping strategy through formal mechanism used by farmers to cope with natural disasters like floods. There is no ex-post risk coping strategy through market based formal mechanism in research area.

Table 6. Ex-post risk coping strategies with formal mechanisms

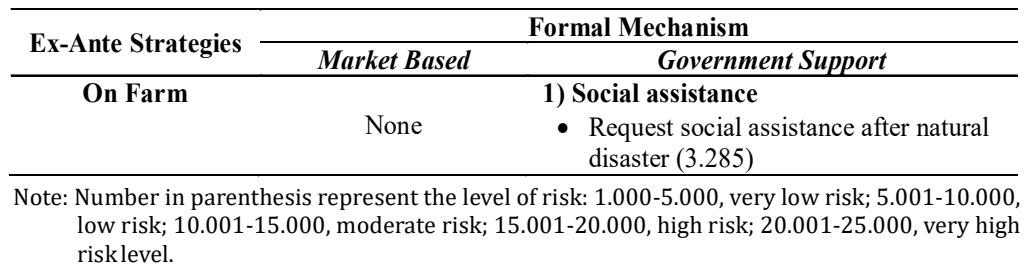

\section{CONCLUSIONS}

Shrimp price volatility and high mortality due to diseases were the most damaging sources of risk experienced by almost the majority of shrimp farmers in East Java, Indonesia. In terms of risk management strategies, small-scale shrimp farmers in East Java like their peers overseas (e.g., Dutch farmers [Meuwissen 2001], Australian farmers [Nguyen et al 2005], Georgian farmers [Lin et al 2008], and American farmers [Hucks et al 2012]) developed several strategies to manage the risks that affect their farms. Results of this study showed a different perspective on risk management strategy by small-scale Indonesian shrimp farmers. This research focused not only on exploring ex-ante and ex-post risk management strategies but also between formal and informal mechanisms.

Small-scale shrimp farmers developed several strategies to manage risks before they occur. Risk avoidance, risk reduction, adoption of advance technology and diversification of income sources are the common approaches for on-farm informal mechanism. For onfarm strategies with formal mechanism farmers: requested for government support in terms of technical assistance and purchased cheaper shrimp fries from the public hatchery. The main ex-ante strategies employed to mitigate sources of risks were: sharing the risk, sharecropping, informal risk pooling, sharing equipment, insurance and marketing contract.

Informal ex-post strategies used to mitigate risk included engaging in informal loan that resulted to loss of savings and use of family labor to streamline consumption and assets. These strategies may reflect the inability of shrimp farmers to access formal loan from financial institutions. Furthermore, to cope with the risk related to natural disasters such as floods, the shrimp farmers only used the formal mechanism by requesting for social assistance from the government. 


\section{REFERENCES}

CHUKU, A. C. 2009. Increasing Resilience and Reducing Vulnerability in Sub-Saharan African Agriculture: Strategies for Risk Coping and Management. African Journal of Agricultural Research Vol. 4(13), 15241535.

DERCON, S. 2005. Risk, Poverty and Vulnerability in Africa. Journal of African Economies Vol.14, 483-488.

FAO. 2016. The State of World Fisheries and Aquaculture: Opportunities and Challenges. Rome: Food and Agriculture Organization of the United Nations.

GUNNING, J. 2012. Risk Management and Coping Mechanisms in Developing Countries. London: Government Office for Science.

HALL, D. K. 2003. Analysis of Beef Producers Risk Management Perceptions and Desire for further Risk Management Education. Review of Agricultural Economics Vol. 25, 430-448.

HARWOOD, J. H. 1999. Managing Risk in Farming: Concepts, Research and Analysis. United States Department of Agriculture, USA: Agricultural Economic Report No 774.

HUCKS, N. T. 2012. Agricultural Risk Management in the Northern Coastal Plains of South Carolina. Journal of Management and Marketing Research, 1-9.

HUNG, L. a. 2013. On-farm Feeding and Feed Management in Whiteleg Shrimp (Litopenaeus vannamei) Farming in Vietnam. in M. N. M.R. Hasan, On-farm Feeding and Feed Management in Aquaculture. (pp. 337-357). Rome: FAO Fisheries and Aquaculture Technical Paper No. 583.

KILAWATI, Y. M. 2015. ICP11 as Biomarker for WSSV Disease in Litopanaeus vannamei. Research Journal of Life Science Vol. 02 No. 03, 183-188.

KNUTSON, R. S. 1998. Southern Farmers' Income Risk. Agricultural and Applied Economics Vol. 30, 35-46.

LEKPRICHAKUL, T. 2009. Ex Ante and Ex Post Risk Coping Strategies: How do subsistence farmers in Southern and Eastern Province of Zambia Cope? In Vulnerability and Resilience of Social-Ecological Systems FY 2008 Project Report. Kyoto, Japan: Research Institute for Humanity and Nature.

LIN, S. J. 2008. Farm-Level Risk Management Using Irrigation and Weather Derivatives. Journal of Agricultural and Applied Economics, 485-492.

MAKOKA, D. 2008. Risk, Risk Management and Vulnerability to Poverty in Rural Malawi. Cuvillier Verlag Göttingen, ISBN-10: 386727746X; ISBN13: 978-3867277464. 
MARTIN, S. 1996. Risk Management Strategies in New Zealand Agriculture and Horticulture. Review of Marketing and Agricultural Economics, 3144.

MINISTRY OF MARINE AND FISHERIES.2015.www.djpb.kkp. go.id/produksi. Retrieved January 05, 2016, from www. djpb. kkp. go.id:ww.djpb.kkp.go.id/index.php/arsip/c/246/Udang-Vanamed a n - U d a n g - W i n d u - M a s i h - A n d a l a n - E k s p o r Indonesia/?category_id=13

MURDOCH, J. 1994. Poverty and Vulnerability. AEA Papers and Procedings 84, (p. 221-225).

NGUYEN, N. W. 2005. Risk Management Strategies by Australian Farmers: Two Case Studies. AFBM Journal Vol. 4 No. 1,23-30.

SUSTAINABLE FISHERIES PARTNERSHIP. 2013. Sustainable Shrimp Industry. Surabaya: Sustainable Fisheries Partnership.

PERDANA, A. 2005. Risk Management for the Poor and Vulnerable. Jakarta: CSIS.

UNDERCURRENTNEWS. 2014. Indonesian Farmers Report Panic Selling on Falling Shrimp Prices. Retrieved from www.undercurrentnews.com: https://www.undercurrentnews.com/2014/05/27/indonesianfarmers-report-panic-selling-on-falling-shrimp-prices/

WORLD BANK. 2005. Managing Agricultural Production Risk. Washington DC: The International Bank for Reconstruction and Development / The World Bank 